Print ISSN: 2053-4086(Print), Online ISSN: 2053-4094(Online)

\title{
THE APPLICABILITY OF FRAUD TRIANGLE IN DETERMINING EMPLOYEE FRAUDS IN PUBLIC SECTOR ENTITIES IN SRI LANKA
}

\author{
Gamlath Mohottige Mudith Sujeewa, Mohd Shukri Ab Yajid, Ali Khatibi, S. M. \\ Ferdous Azam \\ Management \& Science University, Malaysia. \\ mudith@kln.ac.lk,mshukri123@gmail.com, alik@msu.edu.my, \\ drferdous@msu.edu.my
}

\begin{abstract}
The purpose of the study is to identify the determinants of employee frauds in public sector entities in Sri Lanka. The study employed the elements of fraud triangle, opportunity, pressure and rationalization as independent variables and employee fraud as dependent variable. The data is collected from Government Accountants who are working for public sector entities in Sri Lanka and it was analyzed through structural equation modeling with AMOS statistical software. It is found that opportunity and pressure are stisticaly significant in determining employee frauds in public sector entities in Sri Lanka. As such, it is recommended that to design and implement sound internal control and governance framework in public sector entities in Sri Lanka in order to combat against employee fraud. This paper aims at broadening knowledge of top level management of public entities, policy makers, auditors, forensic accountants, regulators and other stakeholders on combating employee frauds in public sector entities in Sri Lanka.
\end{abstract}

KEYWORDS: employee Fraud, opportunity, pressure, rationalization

\section{INTRODUCTION}

Fraud and financial crimes generally, although complex, have existed since time immemorial, evolving over the centuries and becoming more complex and difficult to investigate causing catastrophic consequences to businesses and the economy of a country. Detecting fraud is not an easy task and requires thorough knowledge about the nature of fraud, why it is committed and concealed (ACFE, Report to Nations, 2018). The fraud triangle developed by Cressey in 1953 is a model for explaining the factors that cause someone to commit occupational fraud. It consists of three components which, together, lead to fraudulent behavior: Perceived unshareable financial need, Perceived opportunity and Rationalization (Cressey, 1973). Cressey's fraud theory explained why trust violators commit fraud and was widely used by regulators, professionals and academics.

Many companies expect more return from its employees to maximize its scarce resources for wealth maximization of organizations. It also contributes to an employee ability to rationalize the behaviour even if that employee realizes that the behaviour is about to engage in unethical, illegal or fraudulent, ultimately leading to occupational frauds in organizations (Kassem and Higson, 2012). The Association of Certified Fraud 
Examiners (ACFE) estimated that $5 \%$ of business revenue is lost due to fraud and fraudulent behaviour lasts a median of 18 months before being discovered. The total loss caused by the cases estimated to $\$ 6.3$ billion, with an average loss of case $\$ 2.7$ million. Furthermore, most discoveries occur more by whistle-blowers tips than pre design internal control systems providing evidence that $39.1 \%$ of fraudulent activities are discovered by employee tips (Report to the Nation, 2018).

The nature of fraud means that much of its cost is hidden. Because concealment is an intrinsic component of most fraud schemes, some frauds are never uncovered; further, of the cases that are detected, many are never measured or reported. In addition, most frauds carry substantial indirect costs, including lost productivity, reputational damage and the related loss of business, as well as the costs associated with investigation and remediation of the issues that allowed them to occur. The result is the equivalent of a financial iceberg; some of the direct losses are plainly visible, but there is a huge mass of hidden harm that we cannot see (Report to Nations, ACFE, 2016).

Employee fraud continues to be a significant problem for businesses of all sizes. The generally accepted definition of employee fraud is "Employee fraud is defined as the use of one's occupation for personal enrichment through the deliberate misuse or misapplication of the organization's resources or assets (Fraud Examiner's Manual, 2016). It can negatively influence the capital markets as a consequence of losing the investors' confidence, and can irrevocably damage the company's reputation. Other major implications include significant losses of shareholders values due to abnormal stock price decline, delisting from stock exchange, and material assets sales upon fraud discovery etc.

The survey (Report to Nations, 2018) estimated that the typical organization loses 5\% of revenues in a given year as a result of fraud. The total loss caused by the cases in the study exceeded $\$ 6.3$ billion, with an average loss per case of $\$ 2.7$ million. The median loss for all cases in the study was $\$ 150,000$, with $23.2 \%$ of cases causing losses of $\$ 1$ million or more. Asset misappropriation was by far the most common form of occupational fraud, occurring in more than $83 \%$ of cases, but causing the smallest median loss of $\$ 125,000$. Financial statement fraud was on the other end of the spectrum, occurring in less than $10 \%$ of cases but causing a median loss of $\$ 975,000$. Corruption cases fell in the middle, with $35.4 \%$ of cases and a median loss of $\$ 200,000$ (Report to Nations, 2018).

Therefore it is important to investigate empirically the determinants of employee frauds in public sector entities in Sri Lanka. In summary, the identified problem is to investigate empirically the determinants of employee frauds in public sector entities in Sri Lanka. Accordingly, main objectives of the study is to investigate the determinants of employee frauds in public sector entities in Sri Lanka.

The study formulated three research hypothesis as follows.

H1: There is a significant effect of pressure on employee fraud occurrence

$\mathrm{H} 2$ : There is a significant effect of opportunity on employee fraud occurrence 
European Journal of Accounting, Auditing and Finance Research

Vol.8, No.3, pp.29-37, March 2020

Published by ECRTD-UK

Print ISSN: 2053-4086(Print), Online ISSN: 2053-4094(Online)

H3: There is a significant effect of rationalization on employee fraud occurrence

\section{LITERATURE REVIEW}

\section{Introduction}

Literature review provides extensive details of the literature reviewed for the entire study. It summarizes the key findings from relevant research. The literature review systematically categorizes the fraud triangle theory and its usefulness on identifying determinants of employee frauds and to provide the necessary substance for the overall research findings.

\section{Fraud Triangle}

Cressey, working on his $\mathrm{PhD}$ in criminology (1953), he decided to his dissertation would focus on embezzlers. To serve as a basis for his research, Cressey interviewed about 200 people who had been interacted for embezzling funds. It was formulated the hypothesis as follows; "Trusted persons become trust violators when they conceive of themselves as having a financial problem which is non-sharable, are aware this problem can be secretly resolved by violation of the position of financial trust and are able to apply to their own conduct in that situation verbalization which enable them to adjust their conceptions of themselves as trusted persons with their conceptions of themselves as users of the entrusted finds or property" (Cressey, 1973). Upon, completion of his interviews, he developed what still remains the classic model for the occupational offender. His research was published in other People's money: A Study in the social Psychology of Embezzlement. Over the years, hypothesis formulated in his study has become better known as the fraud triangle. One leg of the triangle represents a Pressure, second leg represents opportunity and the final leg stands for rationalization. The fraud triangle views them as key conditions that tend to be present when fraud occurs. Within each of these broad risk categories, many different and specific potential red flags may be visible within a company.

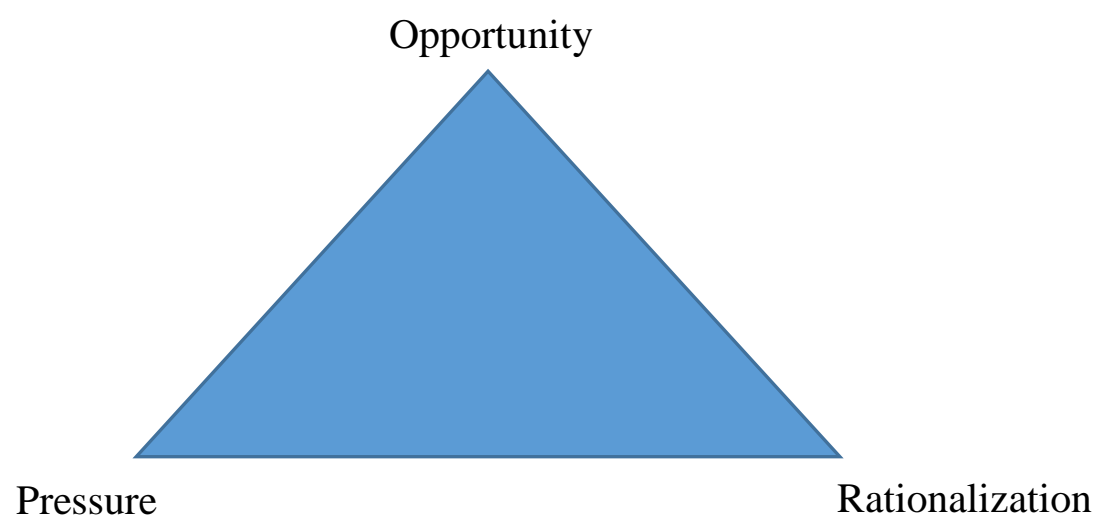

Figure 1: Fraud Triangle 


\section{Pressure}

Pressure, as illustrated by Cressey Donald in 1953, is the incentive that could motivate an individual to be involved in fraud. The pressure could result from personal problems, such as financial pressures or addiction pressures, or from the work environment. Management or other employees may find themselves offered incentives or placed under pressure to commit fraud. For example, remuneration or advancement is significantly affected by individual, divisional, or company performance, individuals may have an incentive to manipulate results or to put pressure on others to do so. Pressure may also come from the unrealistic expectations of investors, banks, or other sources of finance (Gupta, 2015).

\section{Opportunity}

Pressure creates the motive for the crime to be committed, but the employee must also perceive that he has an opportunity to commit the crime without being caught. This Perceived opportunity constitutes the second element. In Cressy's view, there are two components of the perceived opportunity to commit a trust violation; general information and technical skill. General information is simply the knowledge that the employee's position of trust could be violated. Technical skills refers to the abilities needed to commit the violation. These are usually the same abilities that the employees need to have in order to obtain and keep his position in the first place.

\section{Rationalization}

The third and final factor in the fraud triangle is the rationalization. Cressey pointed out that rationalization is not an ex post facto means of justifying a theft that has already occurred. Significantly, rationalization is a necessary component of the crime before it takes place; in fact, it is the part of the motivation for the crime. Because embezzler does not view himself as criminal, he must justify his misdeeds before he ever commits them. The rationalization is necessary so that the perpetrator, can make his illegal behaviour understandable to himself and maintain his concept of himself as a trusted person.

Employee frauds have become a common problem in Sri Lankan context too causing catastrophic consequences to businesses as well as to the economy of the country which is evident by few recent corporate failures. In 2014 high court ordered the winding up of Touchwood Investments PLC following the crisis prevalent in the company and its inability to service the dues owed to the investors. One of the main reason lead to this situation by Touchwood Investments PLC was the manupulation of financial statements in valuing its plantations in accordance with the International Accounting Standard (IAS) 41:Agriculture. The company auditors KPMG, Ford Rhodes, Thornton and Co., qualified the audit opinion; on the ground that the discount rate used (12\%) was too low and did not reflect the long term risk free rate and the premium for other risk factors thus resulting an overstatement of biological assets.

The collapse of the Golden Key Credit Card Company also signal a systemic collapse of some large finance companies as well as banks and could be the impetus for the global financial crisis to spill into Sri Lanka in 2008 which was due to the frauds and 
carries on a finance business in contravention of the provisions of the Finance Act No.78 of 1988. These financial scandales urges the necessity of tools for detecting possible financial statement frauds in the companies.

Furthermore, KPMG fraud study for Sri Lanka (2011/2012) revealed that $83 \%$ of respondents accept that incidents of fraud have increased in Sri Lanka, while 62\% maintained that fraud within their respective industries had increased in the same period. On the other hand, only $51 \%$ accepted that fraud had increased in their own organizations. In turn, it was identified that $70 \%$ of respondents agreed to have the fraud within their organizations, out of which $64 \%$ were from private sector and $89 \%$ from government sector.

In addition to that EY fraud study (2015) found that $91 \%$ of employees say bribery and corruption happens widely in Sri Lanka and 62\% attribute the increase in corruption to tough economic times and increased competition. Further, it exposed that offering entertainment (36\%) is considered justified in aiding business and 44\% think it's acceptable to amend financial reports to provide more positive outlook of results. $46 \%$ say there has been no change in their companies' effort to combat fraud, bribery and corruption over the last two years.

Accordingly, with the aim of understanding the fundamental motives of employee fraud, this exploratory study portraits the employee fraud determinants in public sector entities in Sri Lanka.

\section{METHODOLOGY}

This study employed a mailed survey as a method of data collection. The mail questionnaire method allows for confidentiality, which encourage frankness and is widely used in auditing research. The survey method is particularly appropriate in these circumstances since it is designed with the intention of operationalizing definitions of concepts that reflects the strength of attitudes, perceptions, views and opinions. The respondents of this survey are Government Accountants from public sector entities in Sri Lanka. The sample of Government Accountant is taken from the list of Government Accountants with the Sri Lanka Accountant Service as of 31 December 2019. A simple random technique is applied to construct the sample. A total of 265 Government Accountants responded with usable questionnaires, representing a 31 per cent response rate. It is employed Structural Equation Modelling along with regression analysis to analyze data and AMOS statistical software is used (Siregra et al., 2015; Shafer et al., 2016).

\section{ANALYSIS OF RESULTS AND DISCUSSION OF FINDINGS}

Confirmatory factor analysis investigates the loading of each factor to assess whether they are above the required threshold levels. Thus, it is observed that all items scored factor loading more than 0.5 and remained in the model. Measurement model analysis also involves assessing the Goodness of Fit (GOF) indices of the model. These model 
fit indices of the initial model are presented in table 1 and it provides four absolute fit indices; chi-square significance, Relative chi-square, Root Mean Square Error of Approximation (RMSEA). Incremental fit indices include the Comparative Fit Index (CFI). Further, the table provides Parsimonious Goodness of Fit Index (PGFI) and (PNFI) which are a measure of the parsimony fit. Threshold values of each index are compared with the actual values provided by the model. Accordingly, it can be noted that all the indices are satisfied with the measurement model. Model fit indices of the final measurement model are presented in table 1.

Table 1: Model fit indices of the Final Measurement Model

\begin{tabular}{|l|l|l|l|}
\hline Indices & $\begin{array}{l}\text { Cut-off values and } \\
\text { acceptable } \\
\text { threshold levels }\end{array}$ & $\begin{array}{l}\text { Final model } \\
\text { values }\end{array}$ & Decision \\
\hline Absolute Fit Indices & $<5.00$ & 1.744 & Satisfied \\
\hline Relative $\chi^{2}(\chi 2 /$ df $)$ & $<0.08$ & 0.053 & Satisfied \\
\hline RMSEA & $>0.9$ & 0.956 & Satisfied \\
\hline Incremental Fit Indices & \\
\hline CFI & $>$ & \\
\hline Parsimony Fit Indices & 0.637 & Satisfied \\
\hline PGFI & $>0.5$ & 0.698 & Satisfied \\
\hline PNFI & $>0.5$ &
\end{tabular}

Source: Research data

According to the model, all the criteria are satisfied except chi-square. However, the chi-square of the model is significant ( $p$-value $<0.05$ ). The $p$-value is sensitive to the sample size and usually, it becomes significant for samples exceeding 250 items (Hair, Black, Babin, Anderson, \& Tatham, (2007). Since the current study contains a sample of 265 items, it could expect that the chi-square is not satisfied. Thus the final measurement model confirms that it is fitted with the data as shown in figure 2 . 


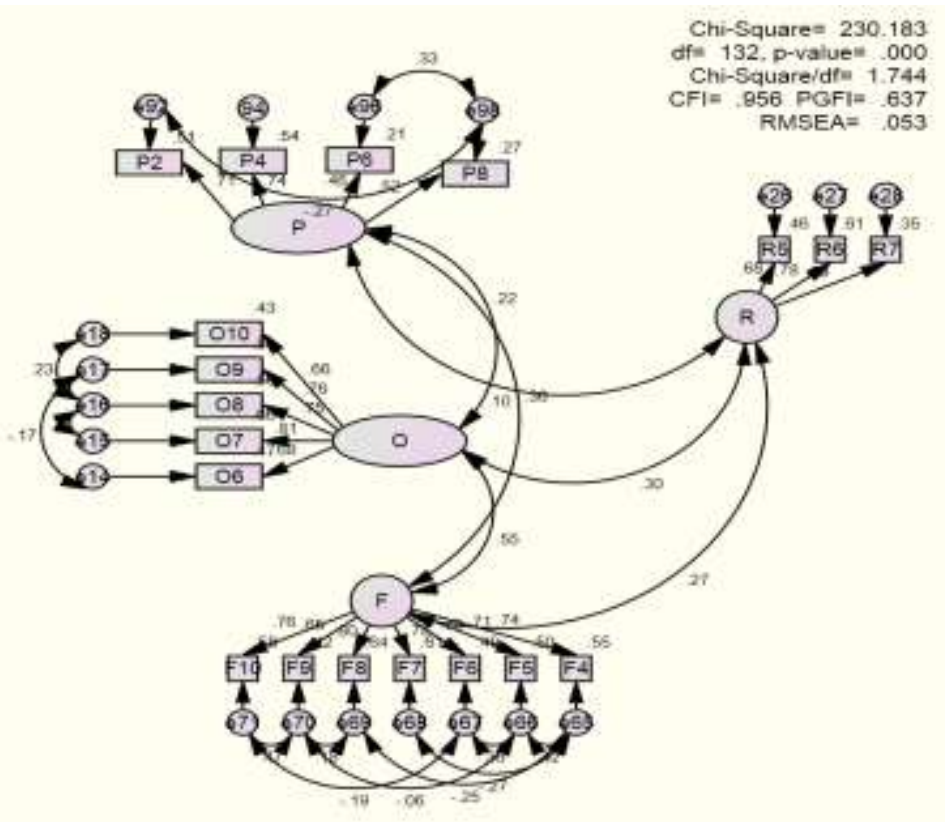

Figure 2: Final Measurement Model

\section{Structural Model}

The measurement model for the variables of the study; pressure, opportunity, rationalization and occurrence of employee fraud are developed using AMOS statistical software. In order to test the hypothesis of the study, a structural model for the regression analysis is developed as shown in figure 3.

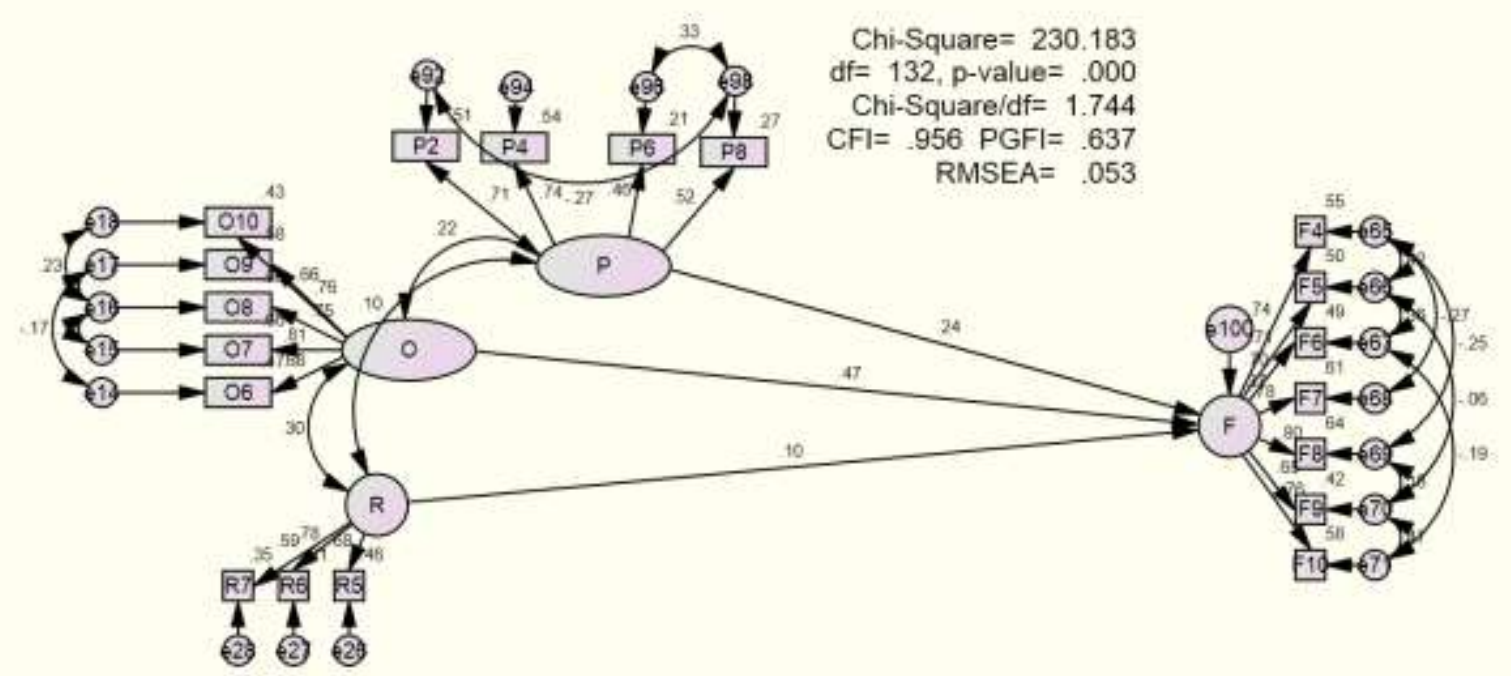

Figure 3: Structural Model 
European Journal of Accounting, Auditing and Finance Research

Vol.8, No.3, pp.29-37, March 2020

Published by ECRTD-UK

Print ISSN: 2053-4086(Print), Online ISSN: 2053-4094(Online)

\section{Hypothesis Testing}

The study has three hypotheses for the direct effect of independent variables into the Employee Fraud. Each hypothesis constructed and it is tested using the results of the regression analysis shown in table 2 .

Table 2: Regression Results

\begin{tabular}{lcccc}
\hline $\begin{array}{l}\text { Independent } \\
\text { variable }\end{array}$ & Estimate & S.E & CR & P-Value \\
\hline Pressure & 0.308 & 0.090 & 3.418 & 0.000 \\
\hline Opportunity & 0.562 & 0.094 & 5.986 & 0.000 \\
\hline Rationalization & 0.099 & 0.067 & 1.471 & 0.141 \\
\hline
\end{tabular}

Source: Research data

As per table 2, the p-value of the pressure lies below the significance level of 0.05 suggesting the influence of pressure on employee fraud occurrence is significant. Accordingly, hypothesis 1 of the study is accepted. As such, the p-value of the opportunity lies below the significance level of 0.05 suggesting the influence of opportunity on employee fraud occurrence is significant. Accordingly, hypothesis 2 of the study is accepted. However, the p-value of the rationalization lies above the significance level of 0.05 suggesting the influence of rationalization on employee fraud occurrence is not significant. Accordingly, hypothesis 3 of the study is rejected.

\section{CONCLUSION, POLICY IMPLICATIONS AND FUTURE RESEARCH}

Employee frauds and manipulations have become a common problem in the today's business context causing catastrophic consequences to businesses as well as to the economy of a country. Detecting employee fraud is not an easy task and requires thorough knowledge about the nature of fraud, why it is committed and concealed. Given this complexity, the current study tried to investigate the applicability of Fraud Triangle in Determining Employee Frauds in Public Sector Entities in Sri Lanka. This models employs three variables Pressure,Opporunity and rationlization as determinats of employee frauds.

For the current study, 265 Government Accountants working in public sector entities in Sri Lanka are used. Results suggested that, Pressure and Opporunity is statitically significant in determing employee frauds in public sector entities in Sri Lanka. However, Rationalization is not significant in determining employee frauds in public sector entities in Sri Lanka. With these results, it can be concluded that Fraud Triangle Thory could be used as a supplementary or risk assessment tool to detect the possible manipulations and employee frauds in public sector entities in Sri Lanka. 
As such it is concluded that top level management in public sector entities in Sri Lanka, Government Auditors,forensic accountants, regulatory authorities and other stakeholders can use Fraud Tringle Theory to detect the red flags of employee frauds in Sri Lankan context.Further, It is recommended to strengthen the control and governance mechanisam to avoid opporunities and making presure situations to comit employee frauds in public sector entities in Sri Lanka.

Further, it is sugested to increase sample size for other employees in public and private sector business entities in Sri lanka for future research.

\section{References}

Association of Certified Fraud Examiners, (2018), Report to Nations, United State of America.

Association of Certified Fraud Examiners, (2016), Report to Nations, United State of America.

ACFE, (2016), Fraud Examiners Manual, Association of Certified Fraud Examiners Austin, TX.

Cressey, D.R. (1953). Other Peoples' Money, Montclair, Glencoe: Free Press.

Cressey, D.R. (1973). Other Peoples' Money: A study in the social psychology of embezzlement. Glencoe: Free Press.

EY, (2015), Fraud Survey 2015. Sri Lanka: EY Forensic.

Gupta, P.K.G.S., (2015), Corporate frauds in India-Perceptions and emerging issues, Journal of Financial Crime, Vol. 22 Iss 1 pp. 79-103.

Hair, J. F., Black, W. C., Babin, B. J., \& Anderson, R. E. (2007), Multivariate Data Analysis, Upper Saddle River, NJ: Prentice hall.

Kassem, R.,Higson, A. (2012). The New Fraud Triangle Model, Journal of Emerging Trends in Economics and Management Sciences (JETEMS), Vol. 3, No. 3, pp.191-195.

KPMG, (2012), Fraud Survey 2012. Sri Lanka: KPMG Forensic.

Shafer, W.E., Simmons, R. S., Yip, R.W.Y., (2016), Social responsibility, professional commitment and tax fraud, Accounting, Auditing \& Accountability Journal, Vol. 29 Issue: 1, pp.111-134.

Siregar, S.V. \& Tenoyo B., (2015), Fraud Awareness Survey of Private Sector in Indonesia, Journal of Financial Crime, Vol. 22, Issue:3, pp. 329-346 